\title{
Contrasting Effects of Grass - Endophyte Chemotypes on a Tri-Trophic Cascade
}

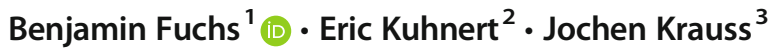

Received: 27 August 2019 / Revised: 5 February 2020 / Accepted: 18 February 2020 / Published online: 3 March 2020

(C) The Author(s) 2020

\begin{abstract}
Systemic grass-endophytes of the genus Epichloë symbiotically infect the above-ground plant parts of many grass species, where they produce alkaloids in a grass- and endophyte-specific manner that are toxic or deterrent to herbivores. An increasing number of studies show cascading negative effects of endophyte-derived alkaloids that extend to higher trophic levels, harming beneficial insects, including those that control aphid populations. Lacewings are one of the major biological aphid controls, and are especially resistant to insecticides and pollutants, but their susceptibility to endophyte infection in the food chain has never been studied. Our study found variability in aphid population growth depending on the endophyte-grass chemotype, where aphid population growth was lowest on chemotypes known for producing high amounts of loline alkaloids. We also showed that larval and pupal development and mortality of the Common Green Lacewing (Chrysoperla carnea) was, in a non-choice experiment, not affected by endophyte infection in the food chain. This is a first indication that lacewings might be resistant to endophyte-derived alkaloids and could be robust biocontrol agents when applied together with endophyte-infected grass, possibly replacing chemical pesticides.
\end{abstract}

Keywords Pest-control $\cdot$ Trophic interactions $\cdot$ Endophytes $\cdot$ Plant defense $\cdot$ Biocontrol $\cdot$ Plant-associated microorganisms $\cdot$ Phytobiome

\section{Introduction}

Pest control in agricultural systems has relied for many decades on the application of chemical pesticides to control plant damage caused by insect herbivores. Recent approaches for the prevention of pest infestation in agricultural systems have moved towards sustainable, environmentally friendly methods based on natural modes of pest control (van Lenteren et al. 2018). Sustainable insect pest control strategies involve natural enemies (top-down control) of insects, such as

Electronic supplementary material The online version of this article (https://doi.org/10.1007/s10886-020-01163-9) contains supplementary material, which is available to authorized users.

Benjamin Fuchs

Benjamin.Fuchs@utu.fi

1 Biodiversity Unit, University of Turku, 20014 Turku, Finland

2 Institute for Organic Chemistry, BMWZ, Leibniz Universität Hannover, Schneiderberg 38, 30167 Hannover, Germany

3 Department of Animal Ecology and Tropical Biology, Biocentre, University of Würzburg, Am Hubland, 97074 Würzburg, Germany predatory and parasitoid insects (Thurman et al. 2017), but further rely on resistant plant cultivars (Stenberg 2017). Plant-associated microorganisms are increasingly being discovered and applied as either entomopathogenic agents or as plant mutualists, boosting defenses against insect pests by increased production of deterrent or toxic metabolites (Gange et al. 2019; Kauppinen et al. 2016; Vega 2018).

Asexual representatives of systemic fungal endophytes (genus Epichloë) infecting cool-season grasses can be plant mutualistic, improving plant traits such as drought tolerance and herbivore resistance (Saikkonen et al. 1998, 2013). The latter trait results from production of several alkaloids such as lolitrem B and ergopeptine alkaloids (e.g., ergovaline), which result in severe diseases in livestock, and peramine, lolines, ergopeptine alkaloids and epoxy-janthitrems, which are toxic and/or deterrent to insect pests (Bush et al. 1997; Leuchtmann et al. 2000; Panaccione et al. 2014). Each grass-endophyte symbiosis produces a specific alkaloid profile in which the amount produced can be affected by biotic and abiotic conditions, but aphid herbivory has not been shown to affect alkaloid concentrations in a common garden study (Bultman et al. 2004; Fuchs et al. 2017b, 2017c; Helander et al. 2016).

Pastures and meadows are often dominated by single grass species which comprise the food supply to livestock 
(Plantureux et al. 2005). Tall fescue (Festuca arundinacea) and perennial ryegrass (Lolium perenne) are distributed worldwide and are agriculturally important grass species (Cougnon et al. 2014; Hoveland 2009). Both species can be found in association with different strains of endophytic fungi. Each plant-endophyte symbiosis produces strain-specific alkaloids leading to different chemotypes (Schardl et al. 2013; Takach et al. 2012; Takach and Young 2014). The common strain (CS) of the asexually reproducing endophytic fungus Epichlö coenophiala is symbiotic with Festuca arundinaceae and produces several pyrrolizidine alkaloids (N-formylloline, $\mathrm{N}$-acetylloline and $\mathrm{N}$-acetylnorloline), the pyrrolopyrazine alkaloid peramine, and the vertebrate-toxic ergot alkaloid ergovaline (Siegel et al. 1990; Ball and Tapper 1999). The Moroccan strain (licensed by AG Research NZ under the code AR 542) of this endophyte produces alkaloids only effective against insects ( $\mathrm{N}$-acetylnorloline and peramine) and is consequently preferably used for pest control on pastures (Ball and Tapper 1999). The common toxic strain of Epichloë festucae var. lolii is symbiotic with Lolium perenne and produces peramine as the main insect-deterring alkaloid, and also the indole diterpene alkaloid lolitrem $\mathrm{B}$ and the ergot alkaloid ergovaline, but none of the pyrrolizidine alkaloids (Siegel et al. 1990; Siegel and Bush 1996).

Aphids are a major pest in agricultural systems, directly damaging the plants by piercing-sucking herbivory, and severely harming pastures and crops by transferring disease viruses ( $\mathrm{Ng}$ and Perry 2004). Grass-endophyte infection can decrease both adult life span and fecundity of certain aphids but these results are often limited to single grass-endophyte associations (e.g. Bastías et al. 2017; Bieri et al. 2009; Meister et al. 2006).

Anti-insect effects of endophytes have been shown for herbivores and higher trophic levels, reducing the fitness of both aphid predators and primary and secondary parasitoids (Bultman et al. 2012; de Sassi et al. 2006; Härri et al. 2008a, $2008 \mathrm{~b})$. The alkaloids peramine and lolitrem B from $L$. perenne infected with E. festucae var. lolii cascade-up the food chain and are probably responsible for fitness reduction of these important predators (Fuchs et al. 2013). To the best of our knowledge, there have been no reports of alkaloids produced by the symbiosis between E. coenophiala and $F$. arundinaceae cascading through the food chain, but negative effects on parasitoids resulted from feeding lolines to their lepidopteran host (Bultman et al. 1997). Some mostly specialized herbivorous insects can sequester alkaloids for their own defense (Trigo 2011), but this remains to be elucidated for endophyte-derived alkaloids.

Larvae of the Common Green Lacewing (Chrysoperla carnea) are one of the main commercially available aphid-pest control agents, but their susceptibility to endophyte-derived alkaloids is unknown. These insects are known to be resistant to certain pesticides and consequently serve as reliable aphid control in contaminated areas (Pree et al. 1989).

In this study, we compared the effects of three different grass-endophyte strains on aphid population growth. Further, we tested how lacewing larval development is affected when larvae are fed exclusively on aphids from Epichlö̈-infected host grass.

\section{Methods and Materials}

Studied Material We analyzed the performance of aphids on five different plant treatments, using three different grassendophyte strains (L. perenne seeds provided by AgResearch NZ, F. arundinaceae seeds provided by University of Georgia). Each strain expresses its own unique alkaloid chemotype, which is mainly responsible for its antiherbivore effects (Saikkonen et al. 2016):

i. Festuca arundinaceae symbiotic with the endophytic fungus Epichloë coenophialia (common strain) (FE+) producing loline alkaloids (N-formylloline, $\mathrm{N}$-acetylloline und $\mathrm{N}$-acetylnorloline), peramine and ergovaline (Ball and Tapper 1999; Siegel et al. 1990);

ii. F. arundinaceae symbiotic with the Moroccan strain of E. coenophiala (FEM) producing the alkaloids Nacetylnorloline and peramine (Ball and Tapper 1999);

iii. F. arundinaceae not infected with an Epichloë endophytic fungi (FE-);

iv. Lolium perenne symbiotic with Epichloë festucae var. lolii (common toxic strain) producing the alkaloids peramine, lolitrem B and ergovaline (LE+) (Siegel et al. 1990; Siegel and Bush 1996);

v. L. perenne not infected with an Epichloë endophytic fungi (LE-).

For each treatment, 12 pots $(13 \times 12 \times 12 \mathrm{~cm})$ were set up in March, and individually filled with soil (Einheitserde classic) and 200 evenly distributed seeds. Pots were randomly grouped and positioned in a greenhouse with $11 \mathrm{hr}$ of day length exposure in March, increasing to $15 \mathrm{hr}$ during May without additional light or temperature treatment, but with a daily water supply (Fig. S1). After 12 weeks of growth (May), seeds had developed between five and eight tillers with fully developed leaves. Plants did not produce inflorescences at this stage.

Epichlö infection of each pot was verified by microscopy following staining one leaf with aniline blue at the end of the experiment. All Epichlö̈-infected plants contained characteristic hyphae, while the uninfected plants showed no hyphae. 
Aphid Performance Anti-aphid effects of different grassendophyte combinations were tested with the bird cherry oat aphid Rhopalosiphum padi, which is a severe pest species of several crop and pasture plants and often transmits the yellow dwarf virus (Whitfield et al. 2015). To test aphid performance, we added 50 adult individuals of $R$. padi aphids (Supplier: Katz Biotech AG http://www.katzbiotech.de) to each plant pot, which was then enclosed in a fine mesh bag to avoid both aphid migration between the treatments and predatory insect infestation (Fig. S2). Each treatment was replicated 12 times. To ensure equal starting conditions, all plants were cut to a height of $15 \mathrm{~cm}$ before adding aphids. Aphid numbers were monitored weekly for four consecutive weeks by counting for $5 \mathrm{~min}$ per plant pot. As $5 \mathrm{~min}$ were not sufficient for some treatments to cover the whole aphid population, total aphid numbers were extrapolated based on the plant area covered during 5 min of counting. Due to an even distribution of aphids, extrapolation was an appropriate measure to estimate population sizes (Fuchs et al. 2017a).

Lacewing Larval Performance The Common Green Lacewing (Chrysoperla carnea) is a representative of the order Neuroptera and is used in integrated pest management strategies. Larvae are carnivorous generalists but are widely used as predators of several aphid pest species (Atlihan et al. 2004). Lacewing eggs were provided by Katz Biotech AG (http:// www.katzbiotech.de). During their three larval stages they are efficient aphid predators with a maximum aphid consumption of approximately 100 individuals per day (Atlihan et al. 2004). To ensure a sufficient number of aphids for feeding lacewing larvae ad libitum until pupation, five plants per treatment received 1000 individuals of $R$. padi aphids; these were reared for 6 weeks before we started feeding them to 20 newly hatched lacewing larvae per plantendophyte combination. Lacewing larvae were kept in petri dishes in a climate cabinet with a constant temperature of $22{ }^{\circ} \mathrm{C}$ and a day/night rhythm of $16 / 8 \mathrm{hr}$. We used plants that had not been used for any previous experiment. Plant age, tiller number and phenology corresponded to the previously described experiment on aphid performance. Lacewing larvae were kept individually in Petri dishes to ensure proper replication and to avoid interactions between individual lacewing larvae as well as pseudo-replication. Plant parts covered with a sufficient number of aphids were added to each petri dish daily. Lacewing developmental status was recorded daily. Aphid numbers on FE+ plants did not reach sufficient population sizes to feed lacewing larvae to pupation. Consequently, data on effects of FE+ in the food chain on the development of lacewings are missing.

Statistics Effects of grass type on aphid population size was analyzed with one-way ANOVA testing aphid number depending on host plant treatment for every week independently (FE-, FEM, FE+, LE-, LE+). Since the ANOVA showed a significant difference, it was followed by Tukey post-hoc tests, tested for every week independently. Plant biomass on the last day had no significant effect on aphid abundances (all $p>0.1$ ), analyzed as a cofactor using a general linear model.

Effects of grass type on lacewing larval and pupal development were analyzed with a one-way ANOVA for each of the larval stages and the cocoon time separately, as well as for the entire developmental time to pupation. Variances were homogeneous and data showed normal distribution. Percentage of lacewing larval mortality was analyzed with a chi-square test. Percentage of dead plant tissue was also analyzed with a chi-square test. Supplementary material contains the entire dataset from the aphid performance assay including aphid numbers (Table S1) and plant biomass with percentage of dead plant tissue (Table S2), and developmental times of lacewing larvae and pupae (Table S3).

\section{Results}

Aphid Performance One week following aphid addition to the plants (week 1), aphid population size on Festuca arundinaceae plants showed higher aphid numbers on FEM and FE- plants compared to FE+ plants (Table 1, Fig. 1). In the following week (week 2) aphid numbers on FE- plants were higher compared to FEM and FE+ plants, and aphid numbers on FEM plants were higher compared to FE+ (Table 1, Fig. 1). Three and 4 weeks after we started the experiment, population size on FE- plants hosted more than double the number of aphids compared to FEM plants, where we counted more than 12 times more aphids on FE- plants as compared to FE+ plants (Table 1, Fig. 1).

Aphid population growth was slower on Lolium perenne plants compared to FE- and FEM, and did not differ between with and without endophyte infection until weeks 3 and 4, when populations on LE- plants showed a similar development to FE- plants, and aphid populations on LE+ plants were similar to FEM plants (Table 1, Fig. 1). By week 1 all other treatments already had higher aphid population sizes than FE+ plants (Table 1, Fig. 1).

Aphid population sizes were similar on endophyte-free $L$. perenne and $F$. arundinaceae plants in week 3 and week 4 (Fig. 1). The phenotype of $F$. arundinacea did not significantly differ between endophyte-infected and endophyte-free plants, with a maximum of dead tissue of approx. $20 \%$ in plants from only one FE- pot. Endophyte-free $L$. perenne plants (LE-) had on average $36 \%$ (max. $70 \%$ ) dead plant tissue at the end of the study, compared to an average of $10 \%$ dead plant tissue in endophyte-infected plants $(\mathrm{LE}+)\left(\mathrm{X}^{2}=15.12\right.$; $p<0,001$ ), (Fig. 2). 
Table 1 Numbers of $R$. padi-aphids (mean \pm S.E) shown for five grass treatments $(F$. arundinaceae $-E$. coenophiala common strain: FE+; F. arundinaceae - Moroccan-strain E. coenophiala: FEM, F. arundinaceae without endophyte: FE-; L. perenne - E. festucae var. lolii common toxic: LE+; L. perenne without endophyte: LE-); ANOVA tests were significant throughout week 1 to 4 ; Tukey posthoc statistics are indicated with letters (see also Fig. 1)

\begin{tabular}{llllll}
\hline Treatment & Week 0 & Week 1 & Week 2 & Week 3 & Week 4 \\
\hline FE+ & $7.2 \pm 1.2 \mathrm{a}$ & $9.4 \pm 1.7 \mathrm{a}$ & $12.3 \pm 3.1 \mathrm{a}$ & $30.9 \pm 7.9 \mathrm{a}$ & $95.1 \pm 22.8 \mathrm{a}$ \\
FE- & $6.2 \pm 0.8 \mathrm{a}$ & $41.9 \pm 4.6 \mathrm{c}$ & $176.4 \pm 15.8 \mathrm{~b}$ & $398.0 \pm 33.4 \mathrm{~b}, \mathrm{c}$ & $1204.5 \pm 201.9 \mathrm{~b}$ \\
FEM & $5.8 \pm 0.6 \mathrm{a}$ & $34.9 \pm 3.3 \mathrm{c}$ & $126.3 \pm 10.1 \mathrm{c}$ & $289.2 \pm 24.6 \mathrm{~d}$ & $594.2 \pm 46.4 \mathrm{c}$ \\
LE+ & $5.8 \pm 0.8 \mathrm{a}$ & $21.8 \pm 2.7 \mathrm{~b}$ & $89.9 \pm 9.6 \mathrm{~b}$ & $261.8 \pm 26.0 \mathrm{~b}$ & $620.3 \pm 59.0 \mathrm{~b}$ \\
LE- & $6.0 \pm 0.9 \mathrm{a}$ & $22.5 \pm 2.1 \mathrm{~b}$ & $107.0 \pm 11.2 \mathrm{~b}$ & $371.3 \pm 31.8 \mathrm{c}, \mathrm{d}$ & $1526.0 \pm 173.1 \mathrm{c}$ \\
ANOVA & $F_{4,55}=0.42 p=0.792$ & $F_{4,55}=17.16 p<0.001$ & $F_{4,55}=31.01 p<0.001$ & $F_{4,55}=30.31 p<0.001$ & $F_{4,55}=20.52 p<0.001$ \\
\hline
\end{tabular}

Lacewing Larval Performance Feeding aphids reared on different host plants to lacewing larvae (FEM, FE-, LE+, LE-) did not result either in differences in lacewing mortality, or in the duration of the larval stages and total developmental time to pupation, analyzed with a one-way ANOVA (Table 2, Fig. 3). We recorded an average developmental time of 26.7 days to adult emergence.

\section{Discussion}

In our experiments, aphid populations were negatively affected by endophyte infection in their host grass, independent of the plant species and its associated symbiotic fungus (i.e. Festuca arundinaceae with Epichloë coenophiala; Lolium perenne with Epichloë festucae var. lolii). We found that grass-endophyte chemotypes, which commonly produce high amounts of loline alkaloids (FE+ see Ball and Tapper 1999) decrease aphid fitness to a greater degree than grass-endophytes which are known to produce less or no loline alkaloids (FEM, LE+ see Siegel et al. 1990;
Ball and Tapper 1999). In addition, our results demonstrate the impact of aphids on endophyte-free perennial ryegrass; an enormous decrease in plant quality resulting in high proportions of dead plant material.

Studies on the effectiveness of grass-endophytes against herbivores have varied widely, depending not only on biotic and abiotic conditions but also on the specific alkaloid composition produced by each grass-endophyte association (Hunt and Newman 2005; Bultman et al. 2006; Fuchs et al. 2017c). Our study demonstrated that chemotypes associated with high loline concentrations are most effective against $R$. padi aphids, as evidenced by the result that it was not even possible to rear sufficient individuals under this condition for our lacewing performance experiment. Observed low aphid population sizes on $F$. arundinaceae infected with $E$. coenophiala common strain illustrated the effectiveness of grass endophytes in aphid control. Grass-endophyte chemotypes producing low amounts of lolines (FEM) or lacking these compounds (LE+ ) hosted lower aphid numbers compared to uninfected grass but significantly more aphids compared to FE+ plants, even after only 1 week, and this persisted to the end of the study. It
Fig. 1 Aphid numbers (mean \pm S.E) per treatment during the 5 weeks of the study. Letters indicate significant differences between treatments (Tukey posthoc test following one-way ANOVA Table 1)

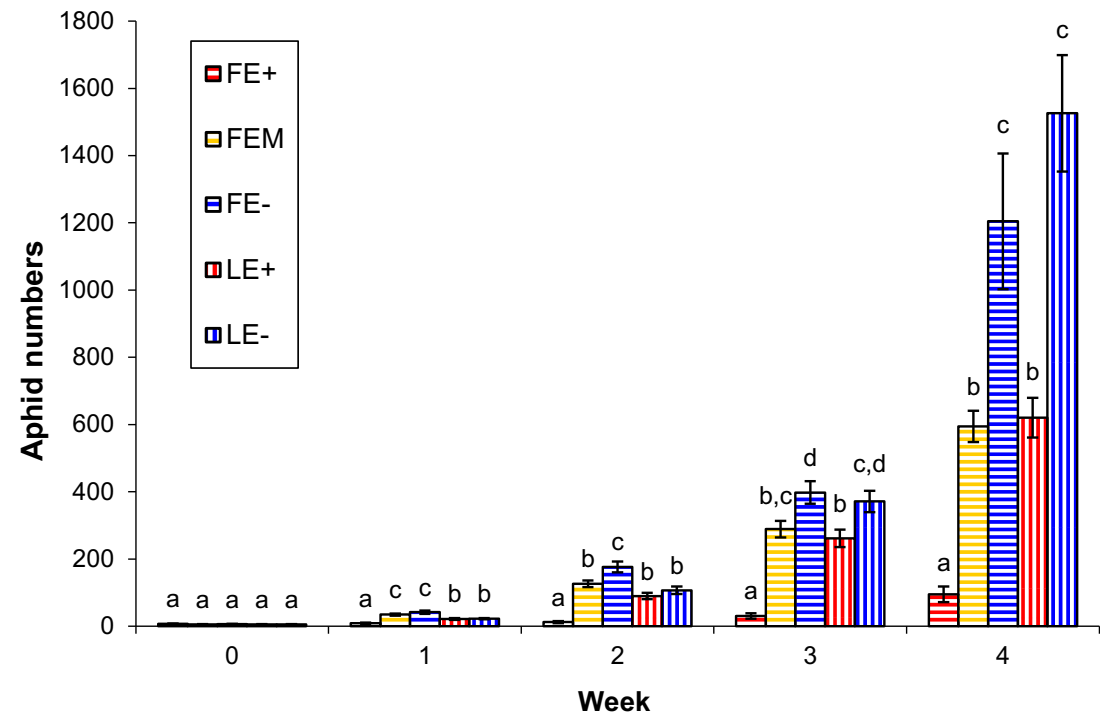


Fig. 2 Plant damage (mean \pm S.E) after 4 weeks of aphid feeding at the end of the experiment. High aphid numbers had detrimental effects on Lolium perenne without endophyte infection (right). Endophyte infected L. perenne plants were viable despite aphid infestation (left). ( $\left.\mathrm{X}^{2}=15.12 ; p<0.001\right)$
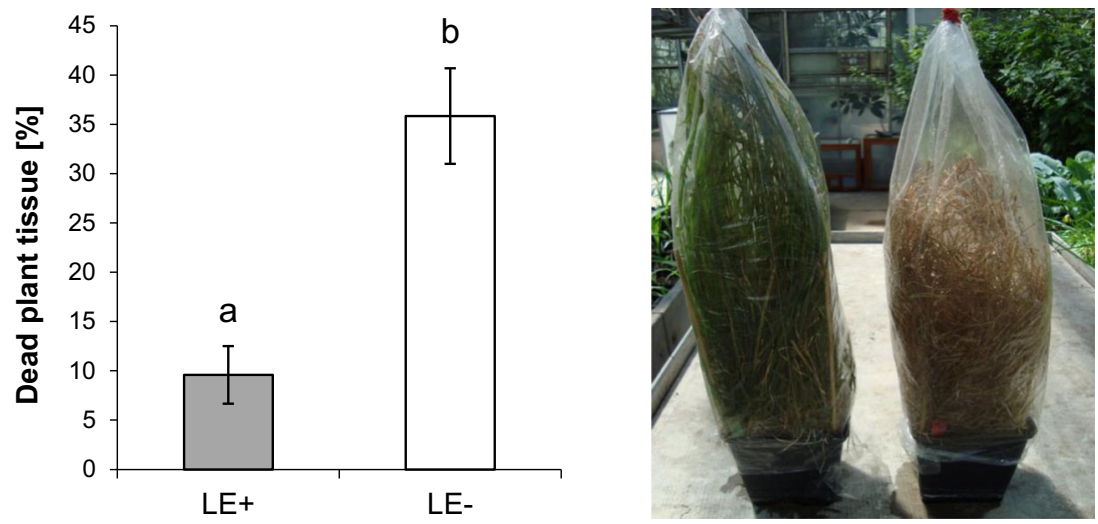

is important to state, that we were not able to measure alkaloid concentrations in the plants as well as aphids due to technical limitations at the time of the study. However, as we used chemically well characterized grass-endophyte combinations, we will rely on the reported alkaloid compositions to draw correlations. We demonstrated the effectiveness of grassendophytes in aphid control, which correlates well with the assumed loline concentrations in the tested plant-endophyte associations (Wilkinson et al. 2000; Hunt and Newman 2005; Bultman et al. 2006). The lack of genes responsible for the biosynthesis of ergovaline, $\mathrm{N}$-formylloline and $\mathrm{N}$-acetylloline in the Moroccan strain of $E$. coenophiala might also contribute to reduced efficiency against herbivores (Ball and Tapper 1999). Planting selected grass-endophyte strains surrounding crop areas may be a first step in decreasing rapid aphid outbreaks, due to the toxic effect of lolines on aphids. Additionally, grass-endophytes alter the emission of volatile organic compounds (VOCs) of their host grass, which potentially repel aphids away from the plant or may even attract predatory insects (Li et al. 2014; Turlings and Erb 2018; Fuchs and Krauss 2019).

Despite their excellent properties for pest control, endophytes can harm beneficial insects by cascading toxins through the food chain from aphids to higher trophic levels (Fuchs et al. 2013); this was shown for the predatory insect the seven-spotted ladybird Coccinella septempunctata, the aphid parasitoid Aphidius ervi, and even a secondary parasitoid Asaphes vulgaris (de Sassi et al. 2006; Härri et al. 2008a, 2008 b). It has been demonstrated, that especially peramine and lolitrem B cascade-up the food chain, which are likely responsible for observed fitness disadvantages found at higher trophic levels (Fuchs et al. 2013). Most of those studies were conducted with loline-free endophyte-infected $L$. perenne, but similar effects were recorded for loline-containing F. arundinaceae on an aphid and lepidopteran parasitoid species (Bultman et al. 1997, 2012).

Lacewings are one of the major natural aphid control agents in agricultural systems and have demonstrated resistance to certain challenging biological and chemical pesticides, which makes them a preferred and reliable biological pest control agent (Pree et al. 1989; Tian et al. 2013). Lacewings were in our experimental setup not susceptible to influences of endophyte infection in their food chain, suggesting that endophyte-mediated bottom-up and lacewingmediated top-down control of aphid populations may be able to coexist without directly affecting each other. Furthermore, bottom-up cascades of alkaloid concentrations may have been low due to plant age (Fuchs et al. 2017c), which may be responsible for missing effects on lacewings. However, younger plants used in a previous study did exhibit cascading negative effects on the fitness of ladybirds as the third trophic level (de Sassi et al. 2006). In order to confirm, whether C. carnea larvae are tolerant to alkaloids, follow-up studies need to incorporate high performance liquid chromatography and mass spectrometry experiments to measure alkaloid levels in aphids and lacewings.

Lolines are classified as pyrrolizidine alkaloids, widespread plant-derived insecticides shaping multi-trophic interactions (Hartmann 1999). Several herbivores have developed mechanisms to cope with plant-produced pyrrolizidine

Table 2 Percentage of mortality and larval developmental times (mean days \pm S.E) of lacewing larvae until adult hatching

\begin{tabular}{lllllll}
\hline Treatment & Mortality [\%] & L1 [d] & L2 [d] & L3 [d] & Pupa [d] & Total [d] \\
\hline FEM & $15 n=20$ & $4.0 \pm 0.1 n=20$ & $3.9 \pm 0.2 n=19$ & $5.2 \pm 0.2 n=18$ & $13.6 \pm 0.2 n=17$ & $26.7 \pm 0.3 n=17$ \\
FE- & $20 n=20$ & $4.2 \pm 0.3 n=19$ & $3.9 \pm 0.1 n=17$ & $4.8 \pm 0.1 n=17$ & $13.8 \pm 0.2 n=16$ & $26.7 \pm 0.4 n=16$ \\
LE+ & $15 n=20$ & $4.1 \pm 0.2 n=20$ & $3.7 \pm 0.1 n=18$ & $5.2 \pm 0.2 n=17$ & $13.5 \pm 0.2 n=17$ & $26.5 \pm 0.4 n=17$ \\
LE- & $15 n=20$ & $3.7 \pm 0.1 n=20$ & $3.9 \pm 0.2 n=18$ & $5.2 \pm 0.2 n=17$ & $14.0 \pm 0.2 n=17$ & $26.9 \pm 0.3 n=17$ \\
X $^{2}$ ANOVA & $X^{2}=1.15 p=0.764$ & $F_{3,75}=1.34 p=0.269$ & $F_{3,68}=0.54 p=0.657$ & $F_{3,65}=1.28 p=0.288$ & $F_{3,63}=1.29 p=0.287$ & $F_{3,63}=0.51 p=0.680$ \\
\hline
\end{tabular}


Fig. 3 Lacewing larval developmental time after feeding on aphids reared on different grass-endophyte hosts. One-way ANOVA see Table 2

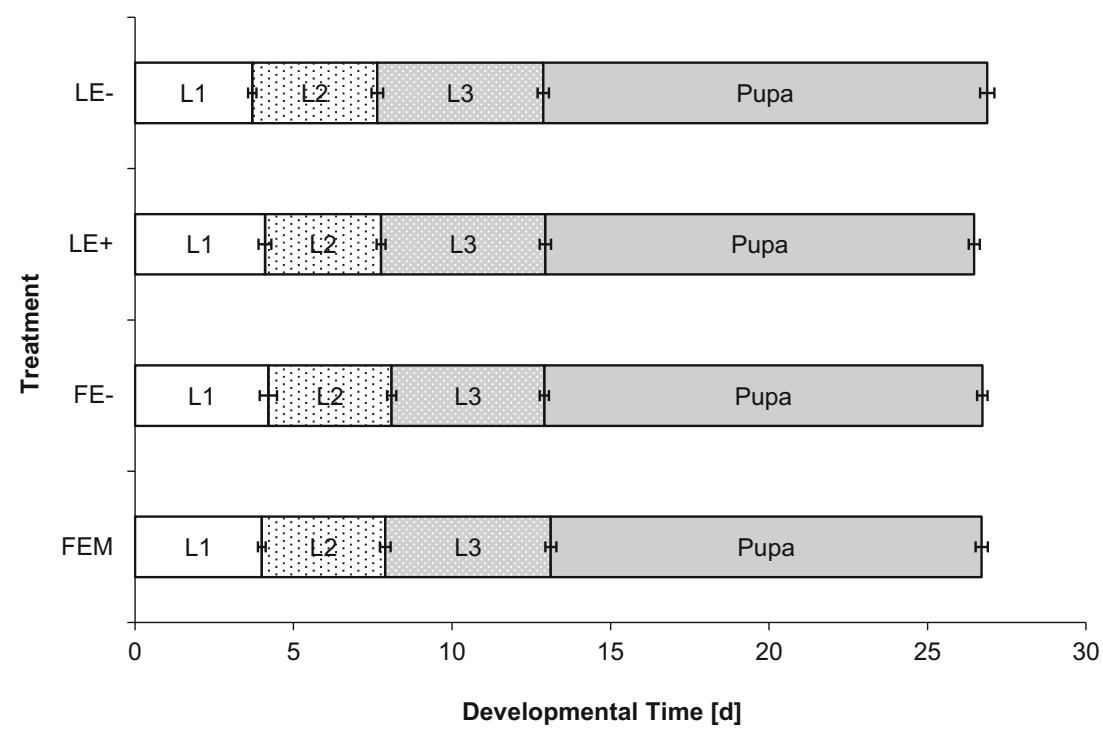

alkaloids and are able to sequester these compounds, thereby improving their own chemical defenses (Trigo 2011). However, in most cases only specialist herbivores show adaptations to these alkaloids, whereas at higher trophic levels variable effects have been observed, differing among plant and insect species (Trigo 2011).

Predatory insects may further be deterred by pyrrolizidinecontaining prey, as shown for lacewings feeding on certain moth eggs (Bezzerides et al. 2004). Future studies should focus on effects of endophyte-derived lolines at higher trophic levels. Furthermore, other beneficial insect species should be tested for their susceptibility to endophyte-derived alkaloids; syrphid fly larvae, for example, are efficient aphid predators (Smith et al. 2008) and were observed in higher numbers on endophyte-infected Lolium perenne during a common-garden study (Fuchs and Krauss 2019). Our results indicate that bottom-up and top-down control of crop pests have the potential to be applied synergistically. Future studies are needed to verify our results under field conditions, where the preference of aphids and their predators to different grass-endophyte strains should be tested.

Our results suggest that $F$. arundinacea infected with E. coenophiala common strain is highly effective against aphid pests and should be considered as an agent capable of reducing aphid populations in grass pastures. The endophyteinfected grass may further be utilized by planting to surround crop fields, preventing aphid outbreaks and decreasing the distribution of vector-borne diseases such as the yellowdwarf virus, which is responsible for tremendous yield losses in cereal crops (Burnett 1990). To prevent unwanted effects on livestock, the Moroccan strain, lacking vertebrate toxic alkaloids, is a "livestock-safe" alternative to the common strain, but produces low levels of lolines and is not as effective against aphids as the common strain. Implementing both bottom-up and top-down strategies in sustainable and biological pest control is a promising strategy for effective biocontrol to replace chemical pesticides. To maximize the effectiveness of merging different approaches in biological pest control, a deeper understanding is needed of how they affect each other both directly and indirectly.

Acknowledgments We thank David Hume (AgResearch NZ) and Donald Wood (University of Georgia) for providing seeds of the different grass-endophyte cultivars.

Funding Information Open access funding provided by University of Turku (UTU) including Turku University Central Hospital. The study was funded by the Academy of Finland (project no. 324523) awarded to BF.

\section{Compliance with Ethical Standards}

Conflict of Interest The authors declare that they have no conflict of interest

Open Access This article is licensed under a Creative Commons Attribution 4.0 International License, which permits use, sharing, adaptation, distribution and reproduction in any medium or format, as long as you give appropriate credit to the original author(s) and the source, provide a link to the Creative Commons licence, and indicate if changes were made. The images or other third party material in this article are included in the article's Creative Commons licence, unless indicated otherwise in a credit line to the material. If material is not included in the article's Creative Commons licence and your intended use is not permitted by statutory regulation or exceeds the permitted use, you will need to obtain permission directly from the copyright holder. To view a copy of this licence, visit http://creativecommons.org/licenses/by/4.0/.

\section{References}

Atlıhan R, Kaydan B, Özgökçe MS (2004) Feeding activity and life history characteristics of the generalist predator, Chrysoperla carnea (Neuroptera: Chrysopidae) at different prey densities. J Pest Sci 77: 17-21. https://doi.org/10.1007/s10340-003-0021-6 
Ball OJ-P, Tapper BA (1999) The production of loline alkaloids in artificial and natural grass/endophyte associations. N Z Plant Protect 52: 264-269

Bastías DA, Ueno AC, Assefh CRM et al (2017) Metabolism or behavior: explaining the performance of aphids on alkaloid-producing fungal endophytes in annual ryegrass (Lolium multiflorum). Oecologia 185:245-256. https://doi.org/10.1007/s00442-017-3940-2

Bezzerides A, Yong T-H, Bezzerides J, Husseini J, Ladau J, Eisner M, Eisner T (2004) Plant-derived pyrrolizidine alkaloid protects eggs of a moth (Utetheisa ornatrix) against a parasitoid wasp (Trichogramma ostriniae). PNAS 101:9029-9032. https://doi.org/ 10.1073/pnas.0402480101

Bieri APS, Härri SA, Vorburger C, Müller CB (2009) Aphid genotypes vary in their response to the presence of fungal endosymbionts in host plants. J Evol Biol 22:1775-1780. https://doi.org/10.1111/j. 1420-9101.2009.01788.x

Bultman TL, Borowicz KL, Schneble RM et al (1997) Effect of a fungal endophyte on the growth and survival of two euplectrus parasitoids. Oikos 78:170-176. https://doi.org/10.2307/3545812

Bultman TL, Bell G, Martin WD (2004) A fungal endophyte mediates reversal of wound-induced resistance and constrains tolerance in a grass. Ecology 85:679-685. https://doi.org/10.1890/03-0073

Bultman TL, Pulas C, Grant L et al (2006) Effects of fungal endophyte isolate on performance and preference of bird cherry-oat aphid. Environ Entomol 35:1690-1695. https://doi.org/10. 1093/ee/35.6.1690

Bultman TL, Aguilera A, Sullivan TJ (2012) Influence of fungal isolates infecting tall fescue on multitrophic interactions. Fungal Ecol 5: 372-378. https://doi.org/10.1016/j.funeco.2011.06.004

Burnett PA (1990) World perspectives on Barley Yellow Dwarf: Proceedings of the International Workshop July, Undine Italy

Bush LP, Wilkinson HH, Schardl CL (1997) Bioprotective alkaloids of grass-fungal endophyte symbioses. Plant Physiol 114:1-7

Cougnon M, Baert J, Waes CV, Reheul D (2014) Performance and quality of tall fescue (Festuca arundinacea Schreb.) and perennial ryegrass (Lolium perenne L.) and mixtures of both species grown with or without white clover (Trifolium repens L.) under cutting management. Grass Forage Sci 69:666-677. https://doi. org/10.1111/gfs. 12102

de Sassi C, Müller CB, Krauss J (2006) Fungal plant endosymbionts alter life history and reproductive success of aphid predators. Proc Biol Sci 273:1301-1306. https://doi.org/10.1098/rspb.2005.3442

Fuchs B, Krauss J (2019) Can Epichloë endophytes enhance direct and indirect plant defence? Fungal Ecol 38:98-103. https://doi.org/10. 1016/j.funeco.2018.07.002

Fuchs B, Krischke M, Mueller MJ, Krauss J (2013) Peramine and lolitrem B from endophyte-grass associations cascade up the food chain. J Chem Ecol 39:1385-1389. https://doi.org/10. 1007/s10886-013-0364-2

Fuchs B, Breuer T, Findling S, Krischke M, Mueller MJ, Holzschuh A, Krauss J (2017a) Enhanced aphid abundance in spring desynchronizes predator-prey and plant-microorganism interactions. Oecologia 183:469-478. https://doi.org/10.1007/s00442016-3768-1

Fuchs B, Krischke M, Mueller MJ, Krauss J (2017b) Herbivore-specific induction of defence metabolites in a grass-endophyte association. Funct Ecol 31:318-324. https://doi.org/10.1111/1365-2435.12755

Fuchs B, Krischke M, Mueller MJ, Krauss J (2017c) Plant age and seasonal timing determine endophyte growth and alkaloid biosynthesis. Fungal Ecol 29:52-58. https://doi.org/10.1016/j. funeco.2017.06.003

Gange AC, Koricheva J, Currie AF et al (2019) Meta-analysis of the role of entomopathogenic and unspecialized fungal endophytes as plant bodyguards. New Phytol. https://doi.org/10.1111/nph.15859

Härri SA, Krauss J, Müller CB (2008a) Trophic cascades initiated by fungal plant endosymbionts impair reproductive performance of parasitoids in the second generation. Oecologia 157:399-407. https://doi.org/10.1007/s00442-008-1094-y

Härri SA, Krauss J, Müller CB (2008b) Fungal endosymbionts of plants reduce lifespan of an aphid secondary parasitoid and influence host selection. Proc R Soc Lond B Biol Sci 275:2627-2632. https://doi. org/10.1098/rspb.2008.0594

Hartmann T (1999) Chemical ecology of pyrrolizidine alkaloids. Planta 207:483-495. https://doi.org/10.1007/s004250050508

Helander M, Phillips T, Faeth SH, Bush LP, McCulley R, Saloniemi I, Saikkonen K (2016) Alkaloid quantities in Endophyte-infected tall fescue are affected by the plant-fungus combination and environment. J Chem Ecol 42:118-126. https://doi.org/10.1007/s10886016-0667-1

Hoveland CS (2009) Origin and history. Tall fescue for the twenty-first century. Agron Monogr 53:3-10. https://doi.org/10.2134/ agronmonogr53.c1

Hunt MG, Newman JA (2005) Reduced herbivore resistance from a novel grass-endophyte association. J Appl Ecol 42:762-769. https://doi.org/10.1111/j.1365-2664.2005.01061.x

Kauppinen M, Saikkonen K, Helander M, Pirttilä AM, Wäli PR (2016) Epichloë grass endophytes in sustainable agriculture. Nat Plants 2: 15224. https://doi.org/10.1038/nplants.2015.224

Leuchtmann A, Schmidt D, Bush LP (2000) Different levels of protective alkaloids in grasses with stroma-forming and seed-transmitted Epichloë/Neotyphodium endophytes. J Chem Ecol 26:1025-1036. https://doi.org/10.1023/A:1005489032025

Li T, Blande JD, Gundel PE et al (2014) Epichloë endophytes alter inducible indirect defences in host grasses. PLoS One 9. https://doi. org/10.1371/journal.pone. 0101331

Meister B, Krauss J, Härri SA et al (2006) Fungal endosymbionts affect aphid population size by reduction of adult life span and fecundity. Basic Appl Ecol 7:244-252. https://doi.org/10.1016/ j.baae.2005.06.002

Ng JCK, Perry KL (2004) Transmission of plant viruses by aphid vectors. Mol Plant Pathol 5:505-511. https://doi.org/10.1111/j.1364-3703. 2004.00240.x

Panaccione DG, Beaulieu WT, Cook D (2014) Bioactive alkaloids in vertically transmitted fungal endophytes. Funct Ecol 28:299-314. https://doi.org/10.1111/1365-2435.12076

Plantureux S, Peeters A, McCracken D (2005) Biodiversity in intensive grasslands: effect of management, improvement and challenges. Integrating efficient grassland farming and biodiversity proceedings of the 13th international occasional symposium of the European grassland federation, Tartu, Estonia, 29-31 august 2005 417-426

Pree DJ, Archibald DE, Morrison RK (1989) Resistance to insecticides in the common green lacewing Chrysoperla carnea (Neuroptera: Chrysopidae) in southern Ontario. J Econ Entomol 82:29-34. https://doi.org/10.1093/jee/82.1.29

Saikkonen K, Faeth SH, Helander M, Sullivan TJ (1998) Fungal endophytes: a continuum of interactions with host plants. Annu Rev Ecol Syst 29:319-343. https://doi.org/10.1146/annurev.ecolsys.29.1.319

Saikkonen K, Gundel PE, Helander M (2013) Chemical ecology mediated by fungal phytes in grasses. J Chem Ecol 39:962-968. https://doi. org/10.1007/s10886-013-0310-3

Saikkonen K, Young CA, Helander M, Schardl CL (2016) Endophytic Epichloë species and their grass hosts: from evolution to applications. Plant Mol Biol 90:665-675. https://doi.org/10.1007/s11103015-0399-6

Schardl C, Young C, Pan J, Florea S, Takach JE, Panaccione DG, Farman ML, Webb JS, Jaromczyk J, Charlton ND, Nagabhyru P, Chen L, Shi C, Leuchtmann A (2013) Currencies of mutualisms: sources of alkaloid genes in vertically transmitted epichloae. Toxins 5:1064 1088. https://doi.org/10.3390/toxins5061064

Siegel MR, Bush LP (1996) Defensive chemicals in grass-fungal endophyte associations. In: Romeo JT, Saunders JA, Barbosa P (eds) 
Phytochemical diversity and redundancy in ecological interactions. Springer US, Boston, pp 81-119

Siegel MR, Latch GCM, Bush LP, Fannin FF, Rowan DD, Tapper BA, Bacon CW, Johnson MC (1990) Fungal endophyte-infected grasses: alkaloid accumulation and aphid response. J Chem Ecol 16:33013315. https://doi.org/10.1007/BF00982100

Smith HA, Chaney WE, Bensen TA (2008) Role of syrphid larvae and other predators in suppressing aphid infestations in organic lettuce on California's central coast. J Econ Entomol 101:1526-1532

Stenberg JA (2017) A conceptual framework for integrated Pest management. Trends Plant Sci 22:759-769. https://doi.org/10.1016/j. tplants.2017.06.010

Takach JE, Young CA (2014) Alkaloid genotype diversity of tall fescue endophytes. Crop Sci 54:667-678. https://doi.org/10.2135/ cropsci2013.06.0423

Takach JE, Mittal S, Swoboda GA, Bright SK, Trammell MA, Hopkins AA, Young CA (2012) Genotypic and chemotypic diversity of Neotyphodium endophytes in tall fescue from Greece. Appl Environ Microbiol 78:5501-5510. https://doi.org/10.1128/AEM. 01084-12

Thurman JH, Crowder DW, Northfield TD (2017) Biological control agents in the Anthropocene: current risks and future options. Curr Opin Insect Sci 23:59-64. https://doi.org/10.1016/j.cois. 2017.07.006
Tian J-C, Wang X-P, Long L-P, Romeis J, Naranjo SE, Hellmich RL, Wang P, Earle ED, Shelton AM (2013) Bt crops producing Cry1Ac, Cry2Ab and Cry1F do not harm the green lacewing, Chrysoperla rufilabris. PLoS One 8:e60125. https://doi.org/10. 1371/journal.pone.0060125

Trigo JR (2011) Effects of pyrrolizidine alkaloids through different trophic levels. Phytochem Rev 10:83-98. https://doi.org/10.1007/ s11101-010-9191-z

Turlings TCJ, Erb M (2018) Tritrophic interactions mediated by herbivore-induced plant volatiles: mechanisms, ecological relevance, and application potential. Annu Rev Entomol 63:433-452. https://doi.org/10.1146/annurev-ento-020117-043507

van Lenteren JC, Bolckmans K, Köhl J et al (2018) Biological control using invertebrates and microorganisms: plenty of new opportunities. BioControl 63:39-59. https://doi.org/10.1007/s10526-017-9801-4

Vega FE (2018) The use of fungal entomopathogens as endophytes in biological control: a review. Mycologia 110:4-30. https://doi.org/ 10.1080/00275514.2017.1418578

Whitfield AE, Falk BW, Rotenberg D (2015) Insect vector-mediated transmission of plant viruses. Virology 479-480:278-289. https:// doi.org/10.1016/j.virol.2015.03.026

Wilkinson HH, Siegel MR, Blankenship JD et al (2000) Contribution of fungal loline alkaloids to protection from aphids in a grassendophyte mutualism. MPMI 13:1027-1033. https://doi.org/10. 1094/MPMI.2000.13.10.1027 